\title{
Sistem Informasi Persediaan Suku Cadang Barang Berbasis Web pada Bengkel Daya Motor Palembang
}

\author{
Nurhachita \\ nurhachita@gmail.com
}

\section{Teknik Informatika, Universitas Bina Darma Palembang}

Diterima: 05 Oktober 2019| Direvisi: 11 November 2019 | Disetujui: 30 Desember 2019

(C) 2019 Program Studi Sistem Informasi Fakultas Sains dan Teknologi,

Universitas Islam Negeri Raden Fatah Palembang, Indonesia

\begin{abstract}
Abstrak: Penelitian ini bertujuan untuk memudahkan mencari persediaan suku cadang barang, setelah menggunakan sistem informasi persediaan suku cadang barang dapat memudahkan pegawai dalam pendataan transaksi pembelian, dapat membantu dalam pendokumentasian data indent dan informasi data konsumen, data barang masuk, data transaksi, mengefisienkan waktu dan memberi solusi dan keakuratan dalam laporan hasil barang masuk dan barang keluar. Sistem ini menggunakan metode perancangan sistem Data Flow Diagram (DFD), sedangkan metode pengembangan sistem menggunakan metode Waterfall, pengujian yang digunakan ialah antarmuka pengguna grafis (GUI). Sistem yang dibuat berbasis web, menggunakan bahasa pemrograman PHP. Hasil penelitian ini dapat membantu pimpinan dan pegawai untuk memudahkan kegiatan-kegiatan transaksi dan melakukan rekapitulasi laporan pada Bengkel Daya Motor.
\end{abstract}

Kata Kunci: Sistem Informasi Persediaan, Data Flow Diagrams (DFD), Web

\begin{abstract}
This study aims to make it easier to find the availability of spare parts, after using the inventory information system can facilitate employees in collecting data on purchase transactions, can help in documenting indent data and consumer data information, data entry goods, transaction data, streamline time and provide solutions and accuracy in the report on incoming and outgoing goods. This system uses the system design method of Data Flow Diagrams (DFD), while the system development method uses the Waterfall method, the test used is a graphical user interface (GUI). The system is made based on web, using the PHP programming language. The results of this study can help leaders and employees to facilitate transaction activities and recap the report at the Daya Motor Workshop.

Keywords: Inventory Information System, Data Flow Diagrams (DFD), Web
\end{abstract}

\section{PENDAHULUAN}

Suku cadang atau sparepart adalah suatu alat yang mendukung pengadaan barang untuk keperluan peralatan yang digunakan dalam proses produksi. Suku cadang merupakan faktor utama yang menentukan jalannya proses produksi dalam suatu perusahaan. Sehingga dapat dikatakan suku cadang ini mempunyai peranan yang cukup besar dalam serangkaian aktivitas perusahaan. Suku cadang motor sangat penting dalam industri otomotif, karena setiap pemilik kendaraan harus di beberapa titik waktu mengganti yang rusak bagian motor. Suku cadang (spareparts) adalah bagian dari alat, mesin atau kendaraan yang disediakan untuk penggantian. Penggantian bagian tersebut perlu atau harus di lakukan karena terjadinya kerusakan. Kerusakan oleh sebab dari luar atau tidak penyediaan suku cadang adalah suatu keharusan untuk menjamin bawah alat mesin (Indrajit \& Djokopranolo, 2006).

Persediaan dapat diartikan sebagai barang-barang yang disimpan untuk digunakan atau dijual pada masa atau periode yang akan datang. Persediaan terdiri dari persediaan bahan baku, persediaan bahan setengah jadi dan persediaan barang jadi. Persediaan bahan baku dan bahan setengah jadi disimpan sebelum digunakan atau dimasukkan ke dalam proses produksi, 
sedangkan persediaan barang jadi atau barang dagangan disimpan sebelum dijual atau dipasarkan. Dengan demikian setiap toko yang melakukan kegiatan usaha umumnya memiliki persediaan. Persediaan sangat dibutuhkan oleh perusahaan untuk menjamin kelancaran aktivitas usahanya. Seperti, jika konsumen ingin membeli sparepart motor berupa suku cadang, jadi admin langsung mengecek barang tersebut melalui sistem ini apakah barang tersebut tersedia atau tidak. Berbagai macam kemungkinan bisa saja mengancam keberlangsungan usaha seperti keterlambatan pasokan bahan baku ataupun kerusakan mesin produksi yang mengakibatkan perusahaan tidak mampu menghasilkan produk. Ketika perusahaan memiliki persediaan baik itu bahan baku ataupun barang jadi, maka perusahaan dapat terus menjalankan aktivitas usahanya meskipun berbagai macam kemungkinan di atas terjadi. Pengelolaan persediaan barang disesuaikan dengan prediksi permintaan pasar. Hal ini memudahkan perputaran barang sehingga tidak terjadi penumpukan barang. Selain itu pengelolaan jumlah persediaan barang juga meminimalkan pengeluaran modal yang terlalu besar dan juga meminimalkan tingkat kerugian diakibatkan rusaknya barang karena lama penyimpanan.

Sistem Informasi berbasis web sebagai salah satu representasi dari bidang teknologi sistem informasi. Sistem informasi berbasis web merupakan media informasi yang sangat berkembang pesat sekarang ini. Dengan sistem informasi berbasis web, semua orang dapat menampilkan informasi yang dapat dinikmati oleh seluruh pengguna internet. Bengkel kendaraan dengan berbagai nama yang ada di masyarakat, kegiatan utama yang dilakukan adalah merawat dan memperbaiki atau melakukan pemeliharaan kendaraan. Terdapat bengkel umum yaitu bengkel yang mengerjakan semua kerusakan pada semua komponen atau sistem pada kendaraan dan terdapat bengkel khusus atau spesialis, yang hanya mengerjakan pemeliharaan untuk satu atau beberapa komponen atau sistem yang ada pada kendaraan yang memerlukan suku cadang tertentu, salah satu bengkel yang menyediakan service untuk kendaraan motor yaitu bengkel Daya Motor, dalam melaksanakan transaksi penjualan terutama untuk persediaan suku cadang masih mengalami permasalahan karena masih menggunakan buku besar untuk dilakukan rekapitulasi ke dalam penyimpanan komputer dengan menggunakan Microsoft Excel, yaitu petugas dalam melayani proses penjualan masih banyak mendapatkan kendala diantaranya pembuatan nota penjualan sering berbeda-beda antara petugas toko dengan administrasi, memberikan informasi persediaan atau stok suku cadang dengan melihat di gudang masih tersedia atau tidak barang yang diinginkan oleh konsumen. Hal ini mengakibatkan proses pengolahan data atau penambahan data barang suku cadang, dimana bagian administrasi sering keliru tentang barang masuk dan barang keluar diakibatkan kurang efektif dan berdampak kesalahan dalam pembuatan laporan harian, mingguan serta bulanan maupun rekapitulasi tahunan untuk data suku cadang yang dibutuhkan.

Hal yang sebaliknya juga terjadi ketika persediaan suku cadang barang di Bengkel Daya Motor ini terkadang mengalami kehabisan persediaan suku cadang dalam setiap tahunnya terutama ketika menjelang hari raya. Permintaan yang banyak dari pelanggan menyebabkan suku cadang di Bengkel Daya Motor mengalami out of order (kehabisan stok). Suku cadang yang biasa terpakai adalah suku cadang yang bersifat dalam suku cadang rutin. Suku cadang rutin ini antara lain filter udara, oli, kampas rem depan, kampas rem belakang, packing drain, balance weight, busi, minyak rem, filter bensin, filter oli, ban, suspensi, bohlam lampu motor depan dan belakang, aki baterai, dan mur motor. Masalah tersebut terjadi dikarenakan kurang efektif penentuan persediaan terhadap suku cadang. Dimana, dalam pengolahan data persediaan suku cadang di Bengkel Daya Motor ini masih belum tersedia sistem dalam menentukan persediaan suku cadang tiap periode ke depan.

Beberapa tinjauan pustaka yang berkaitan dengan Persediaan Barang antara lain: (Nugrahanti, 2015) dalam seminar nasional dengan judul "Perancangan Sistem Informasi Inventory Sparepart Mesin Photocopy Dengan Menggunakan Visual Delphi 7 (Studi Kasus di UD). Eka Taruna Madiun)" dari hasil penelitian ini menghasilkan suatu aplikasi program yang dapat melakukan kontrol persediaan sparepart dan memberikan laporan update stok

Volume 5, Nomor 2, Desember 2019 
Dengan adanya penelitian ini, maka akan mempermudah proses monitoring stok barang yang masuk maupun keluar. Bahasa pemrograman DELPHI 7 dan MySQL sebagai database. Pemodelan yang dipakai Data Flow Diagram (DFD) dan relasi antar entitas (ERD).

(Pranggono et al., 2016) dalam jurnal dengan judul "Sistem Informasi Persediaan Barang Secara Multiuser Pada Apotek Kinasih Bulu Sukoharjo" dari hasil penelitian ini permasalahan bagian penjualan belum mengetahui secara pasti jumlah persediaan barang yang siap untuk di keluarkan dan barang mana yang harus terlebih dahulu di keluarkan, Pengembangan sistem informasi ini menggunakan metode Rata-Rata Bergerak dengan bahasa pemodelan DFD (Data Flow Diagram). Pada pemrograman berbasis web, PHP serta menggunakan mesin basis data MySQL.

(Yulianti \& Yupianti, 2012) dalam jurnal dengan judul "Sistem Informasi Persediaan Barang Pada PT. Surya Nusa Bhaktindo Bengkulu" dari hasil penelitian ini Pengembangan sistem informasi ini menggunakan metode Rata-Rata Bergerak dengan bahasa pemodelan Data Flow Diagram (DFD) dan relasi antar entitas (ERD). Bahasa pemrograman Visual Basic 6.0 sedangkan file (basis data) atau database-nya dibuat menggunakan Microsoft Access.

(Rahmad \& Setiady, 2014) dalam jurnal dengan judul "Perancangan Sistem Informasi Inventory Spare Part Elektronik Berbasis Web PHP (Studi CV. Human Global Service Yogyakarta)" dari hasil penelitian ini sistem informasi yang dibutuhkan oleh perusahaan ini adalah pembuatan aplikasi dalam pengolahan serta pendataan data persediaan barang (inventory) khususnya persediaan sparepart serta laporan yang terkomputerisasi agar pencatatan arus barang masuk servis dan selesai servis dapat secara cepat, tepat, dan akurat. Sistem informasi tersebut dengan menggunakan Metode FIFO (Firts In Firts Out), bahasa pemrograman $P H P$ dan MySQL sebagai database. Pemodelan yang dipakai Data Flow Diagram (DFD).

\section{METODOLOGI PENELITIAN}

Menurut (Pressman, 2012), Model air terjun (waterfall) kadang dinamakan siklus hidup klasik (Classic Life Cycle), dimana hal ini menyiratkan pendekatan yang sistematis dan berurutan (sekuensial) pada pengembangan perangkat lunak, yang dimulai dengan spesifikasi kebutuhan pengguna dan berlanjut melalui tahapan-tahapan perencanaan, pemodelan, konstruksi serta penyerahan sistem/perangkat lunak ke para pelanggan/pengguna, yang diakhiri dengan dukungan berkelanjutan pada perangkat lunak lengkap yang dihasilkan yaitu terdapat pada Gambar 1.

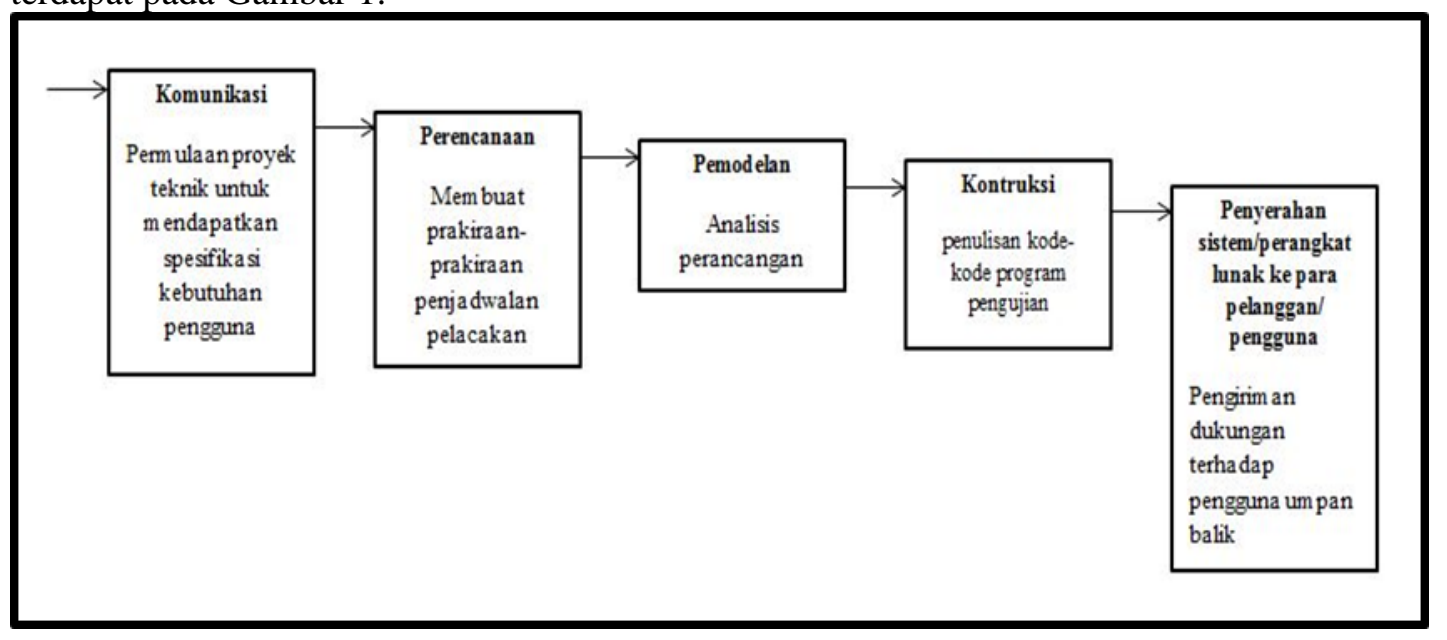

Gambar 1. Model Waterfall

Sumber: (Pressman, 2012) 
Berikut adalah penjelasan tahapan dalam metode Model air terjun (Waterfall):

1) Komunikasi

Merupakan tahap pertama, yang dilakukan menguraikan hasil wawancara. Pada tahapan ini dilakukan pengumpulan data, melakukan pertemuan dengan pengguna, dimana pengguna disini ialah admin, dan pemilik bengkel pada Bengkel Daya Motor Palembang.

\section{2) Perencanaan}

Merupakan lanjutan dari tahap komunikasi. Pada tahap ini akan menghasilkan data yang berhubungan dengan keinginan dalam pembuatan software, termasuk rencana yang akan dilakukan.

\section{3) Pemodelan}

Merupakan lanjutan setelah tahap komunikasi dan perencanaan. Pada tahap ini dilakukan analisis dan perancangan software yang dapat diperkirakan sebelum dibuat koding dimana perancangan yang dibuat menggunakan Data Flow Diagram (DFD). Pada tahap ini berfokus pada perancangan sistem dan rancangan interface. Tahapan ini akan menghasilkan dokumen yang disebut kebutuhan perangkat lunak (software requirement).

4) Kontruksi

Merupakan lanjutan setelah tahap komunikasi, perencanaan dan pemodelan. Tahap ini merupakan penulisan kode-kode program serta pengujian program. desain yang telah dibuat sebelumnya harus diimplementasikan ke dalam program perangkat lunak. Hasil dari tahap ini adalah program komputer sesuai dengan desain yang telah dibuat pada tahap desain sebelumnya. Pengujian yang digunakan ialah antarmuka pengguna grafis (GUI) karena komponen penggunaan ulang sekarang adalah bagian yang umum dari lingkungan pembangunan GUI, pembuatan antarmuka pengguna menjadi lebih singkat dan lebih tepat (Pressman, 2012).

5) Penyerahan sistem perangkat lunak ke para pelanggan/pengguna

Pada tahap ini tidak menutup kemungkinan sebuah perangkat lunak mengalami perubahan ketika sudah dikirimkan ke pengguna. Perubahan bisa terjadi karena adanya kesalahan yang muncul dan tidak terdektesi saat pengujian atau perangkat lunak harus beradaptasi dengan lingkungan baru.

\section{HASIL DAN PEMBAHASAN}

\subsection{Rancangan Sistem}

\section{1) Komunikasi}

Setelah melakukan pengamatan dan analisis pada bengkel Daya Motor dapat diketahui sistem yang sedang berjalan selama ini masih kurang efektif diantaranya jika konsumen ingin mengetahui sparepart yang konsumen inginkan. Konsumen harus menanyakan terlebih dahulu kepada admin. Lalu admin mengecek barang apa yang diinginkan oleh konsumen tersedia atau tidak. Jika barang tersebut tersedia atau tidak, maka admin memberitahukan kepada konsumen bahwa tentang kondisi barang tersebut. Jika barang tersedia maka barang tersebut langsung di pasang. Jika barang tidak tersedia admin akan menanyakan kepada konsumen mau indent atau tidak? Kalau konsumen setuju barang langsung dicatat admin di dalam buku besar indent dan dipesankan. 
Berikut adalah gambaran alur sistem yang sedang berjalan pada bengkel Daya Motor:

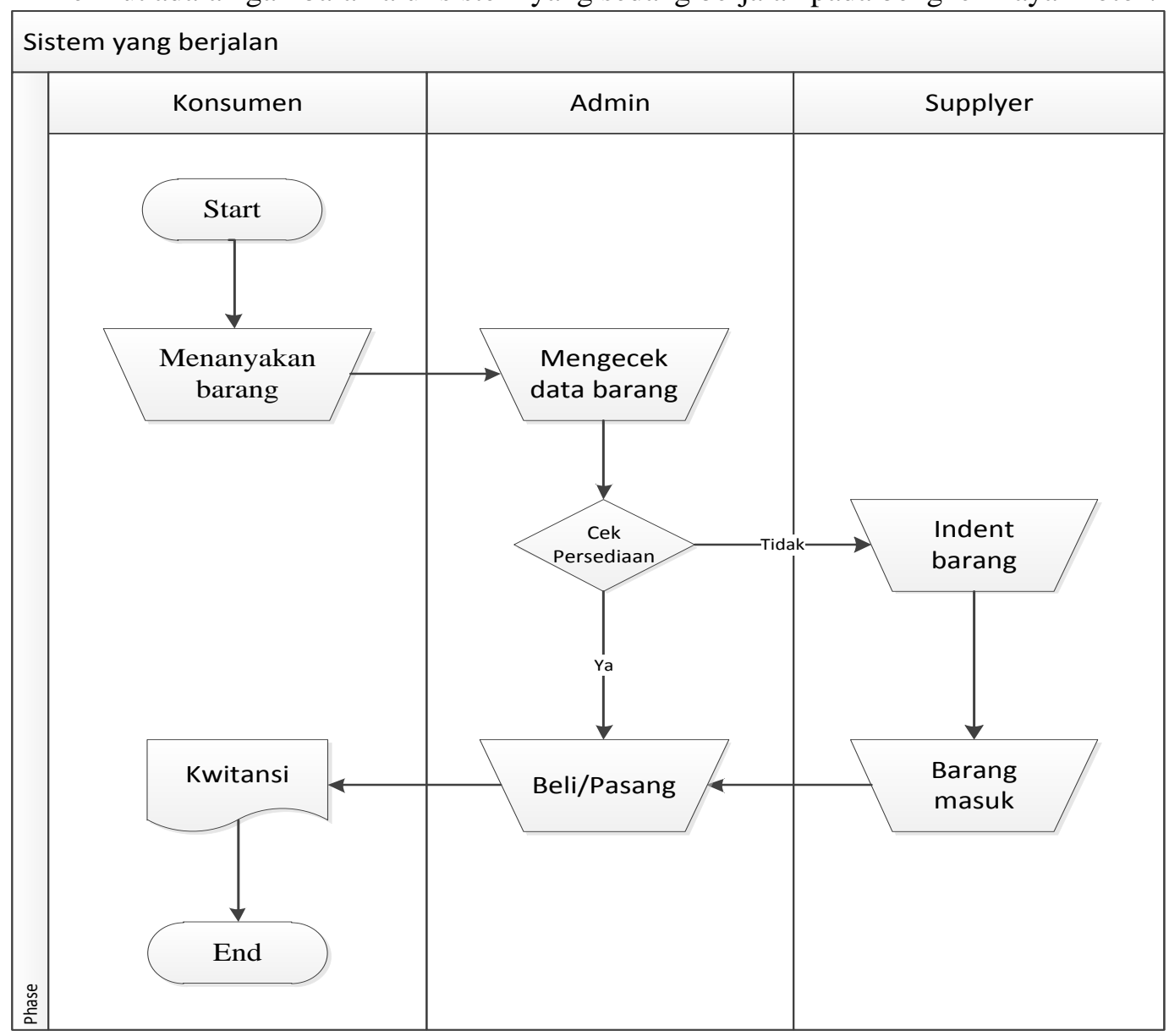

Gambar 2. Flowchart Sistem Yang Sedang Berjalan

\section{2) Perencanaan}

Penjadwalan yang jelas diperlukan dalam perencanaan membuat sistem, sehingga tahapan proses pembuatan sistem yang dapat berjalan dengan baik dan lancar, tidak hanya itu penjadwalan juga mempengaruhi lamanya waktu proses pengerjaan dan kebutuhan biaya, penjadwalan disusun secara detail, sesuai dengan metode pengembangan sistem yang digunakan mulai dari tahap komunikasi, tahap perencanaan, tahap pemodelan, tahap konstruksi, dan yang terakhir tahap penyerahan

\section{3) Pemodelan}

Data Flow Diagram (DFD) merupakan cara atau metode untuk membuat perancangan sebuah sistem yang berorientasi pada alur yang bergerak pada sebuah sistem selanjutnya. Dalam pembuatan sistem informasi $D F D$ sering digunakan. $D F D$ dibuat oleh para analis untuk membuat sebuah sistem yang baik dimana $D F D$ ini nantinya diberikan kepada para programmer untuk melakukan proses coding (Shalahuddin, 2018).

Data Flow Diagram (DFD) level 0 atau diagram konteks pada sistem informasi persediaan suku cadang barang. Pada Gambar 3 menjelaskan proses sistem yang diusulkan, pada sistem ini mempunyai 3 entitas yaitu: entitas admin, entitas kasir, dan entitas pimpinan. Masing-masing entitas mempunyai aliran data, baik itu data masuk dan data keluar. Entitas admin mempunyai data masukan seperti: data user, data konsumen, data barang masuk, data master barang, data kategori, data pegawai, dan data supplier. Entitas admin mempunyai data keluaran yaitu: faktur. Entitas kasir mempunyai data masukan seperti: transaksi, data konsumen dan data indent. Entitas kasir mempunyai data keluaran seperti: data supplier dan 
data indent. Entitas pimpinan mempunyai data keluaran seperti: laporan data konsumen, laporan data barang masuk, laporan data transaksi, laporan data indent.

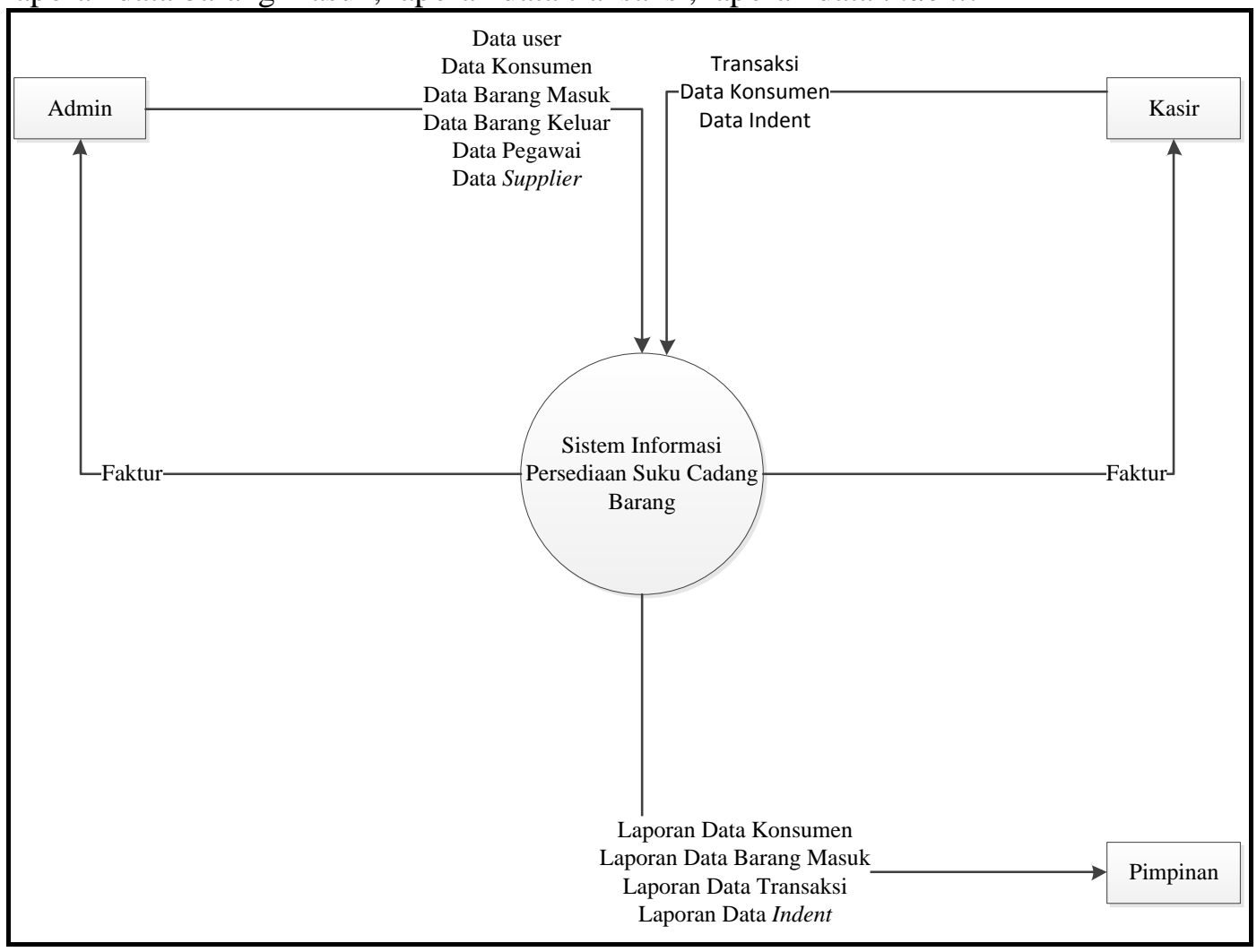

Gambar 3. Diagram Konteks

Data Flow Diagram (DFD) level 1 pada sistem informasi persediaan suku cadang barang. Pada Gambar 4 terdapat 9 aliran data diantaranya yaitu user, barang, barang masuk, barang keluar, transaksi, indent, pegawai, konsumen, dan supplier. Proses-proses yang terdapat pada sistem baru yaitu mengelola data user, mengelola data barang, mengelola data barang masuk, mengelola data master barang, mengelola kategori, mengelola data transaksi, mengelola data indent, mengelola data karyawan, mengelola data konsumen, mengelola data supplier, dan report. $D F D$ sistem baru diatas, proses-proses yang terdapat pada sistem perencanan dan pengendalian persediaan ini telah memiliki pengelolaan data yang disimpan ke tabel database, sehingga data-data yang dikelola saling berinteraksi dan dapat menghasilkan informasi. 


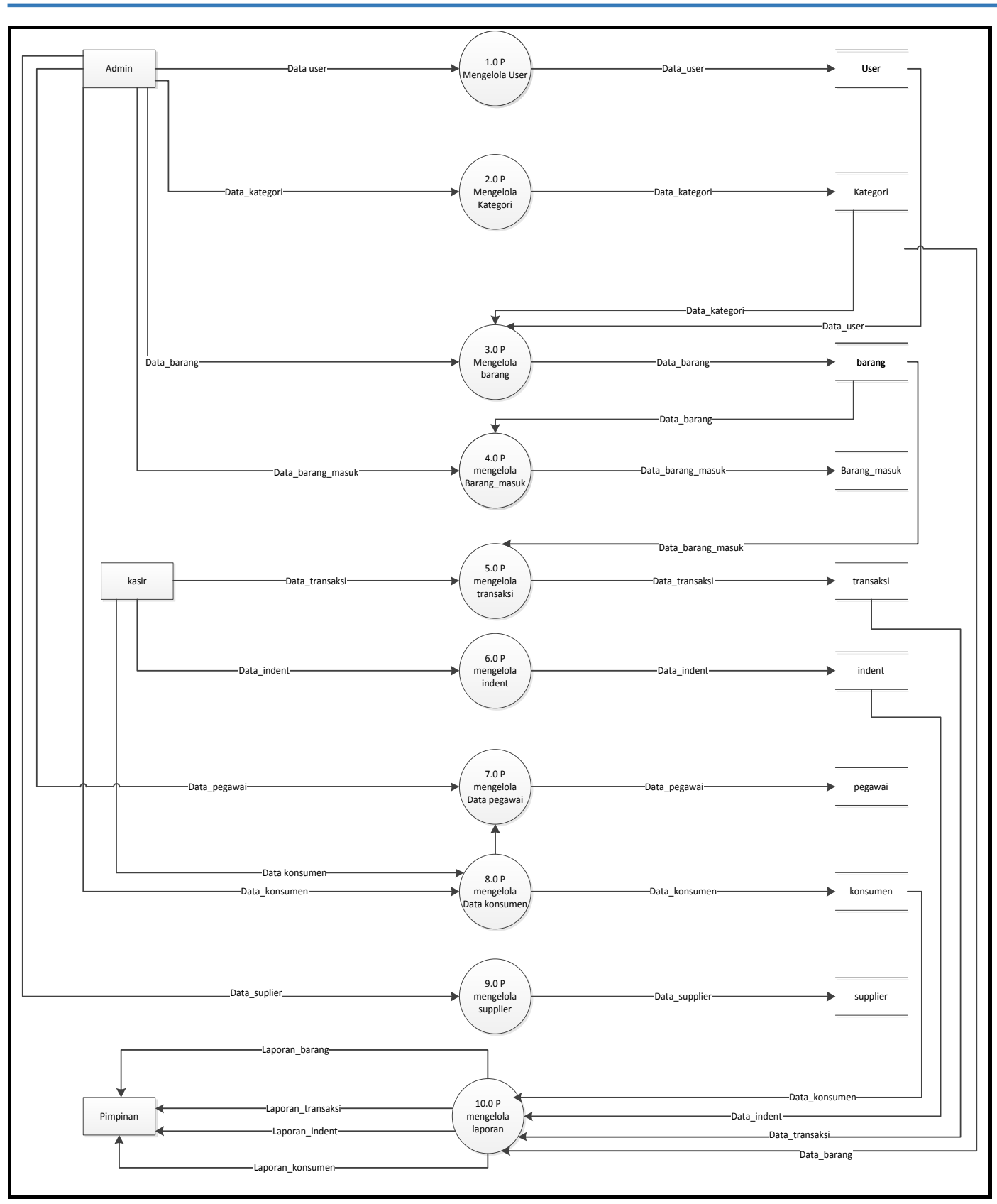

Gambar 4. Data Flow Diagram Level 1

Entity Relationship Diagram (ERD) menjelaskan objek data, atribut, keterhubungan, dan berbagai jenis indikator pada sistem yang dibangun dan siapa saja yang berinteraksi dengan sistem. ERD pada penelitian ini dapat dilihat pada Gambar 5. 


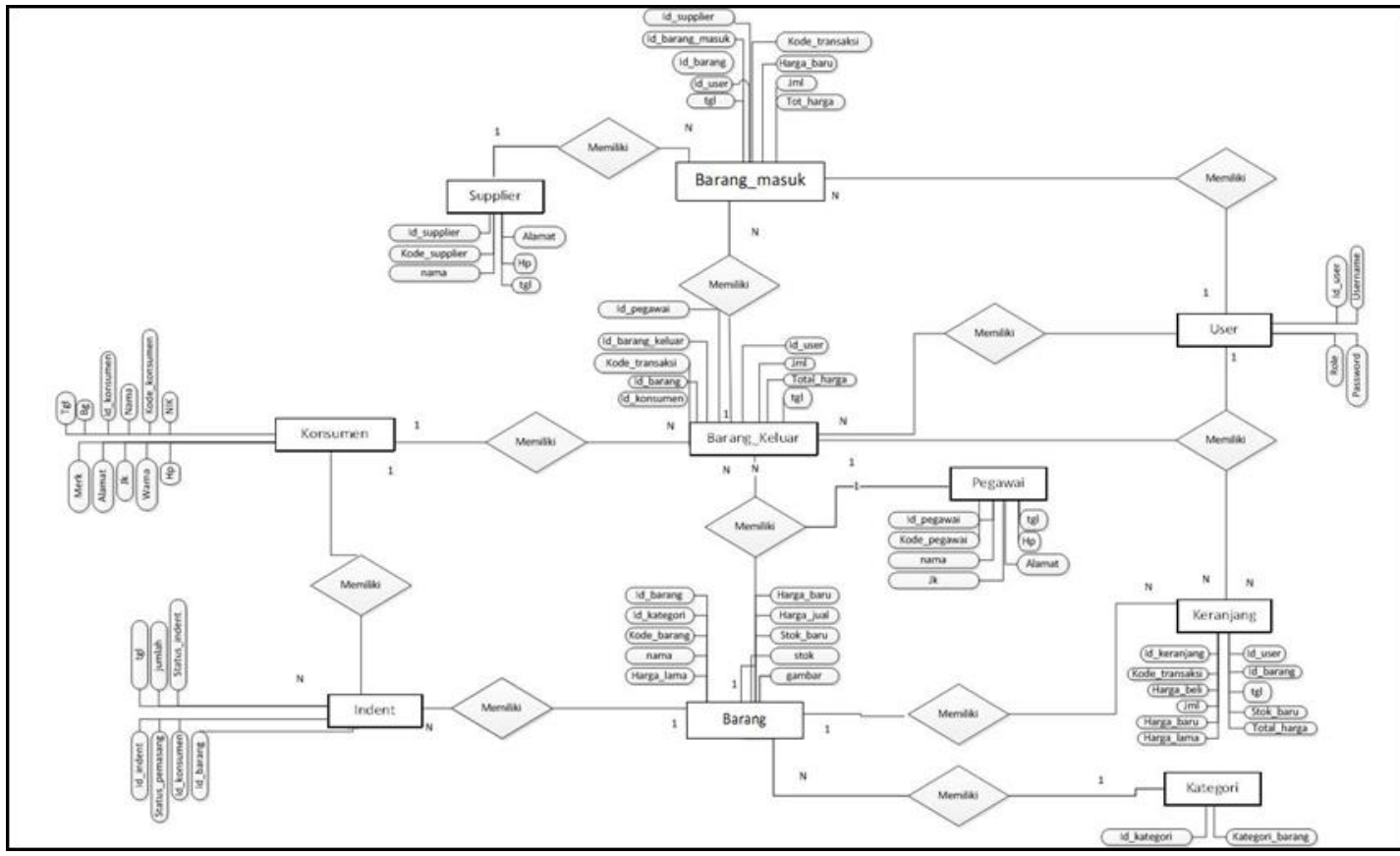

Gambar 5. Entity Relationship Diagram

\section{4) Konstruksi}

Pada tahap ini pengujian yang digunakan yaitu antarmuka pengguna grafis (GUI), penulis melakukan uji coba terhadap sistem yang telah dikembangkan. Hasil dari tahap ini adalah program komputer sesuai dengan desain yang telah dibuat pada tahap desain sebelumnya. Pengujian yang digunakan ialah antarmuka pengguna grafis (GUI) karena komponen penggunaan ulang sekarang adalah bagian yang umum dari lingkungan pembangunan $G U I$, pembuatan antarmuka pengguna menjadi lebih singkat dan lebih tepat.

Pengujian untuk mengetahui kinerja kerja dari aplikasi dilakukan dengan melakukan pengujian kepada pengguna aplikasi yang dikembangkan. Dalam pengujian ini diambil 10 responden dari para karyawan pada Bengkel Daya Motor. Responden diberikan pertanyaan berupa kuesioner dan hasil kuesioner dapat dilihat pada Tabel 1.

\section{Tabel 1. Tabel Hasil Kuesioner Pengguna Aplikasi}

\begin{tabular}{|c|c|c|c|c|c|}
\hline No. & Pertanyaan & $\begin{array}{l}\text { Sangat } \\
\text { Setuju }\end{array}$ & Setuju & $\begin{array}{l}\text { Kurang } \\
\text { Setuju }\end{array}$ & $\begin{array}{l}\text { Tidak } \\
\text { Setuju }\end{array}$ \\
\hline 1. & $\begin{array}{l}\text { Apakah interface sistem yang } \\
\text { dibuat telah user frriendly } \\
\text { (mudah digunakan } \\
\text { pengguna) }\end{array}$ & 2 & 8 & 0 & 0 \\
\hline 2. & 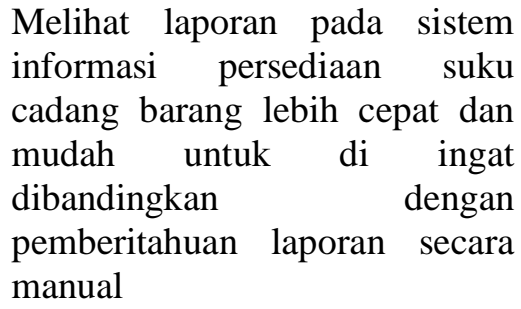 & 2 & 7 & 1 & 0 \\
\hline 3. & $\begin{array}{l}\text { Apakah form pengisian pada add } \\
\text { barang telah sesuai dengan form } \\
\text { pengisian manual }\end{array}$ & 0 & 8 & 2 & 0 \\
\hline 4. & $\begin{array}{l}\text { Sistem informasi persediaan } \\
\text { suku cadang barang dapat }\end{array}$ & 1 & 9 & 0 & 0 \\
\hline
\end{tabular}

Volume 5, Nomor 2, Desember 2019 


\begin{tabular}{|c|c|c|c|c|c|}
\hline No. & Pertanyaan & $\begin{array}{l}\text { Sangat } \\
\text { Setuju }\end{array}$ & Setuju & $\begin{array}{l}\text { Kurang } \\
\text { Setuju }\end{array}$ & $\begin{array}{l}\text { Tidak } \\
\text { Setuju }\end{array}$ \\
\hline & $\begin{array}{l}\text { membantu kepala cabang dan } \\
\text { kepala wilayah untuk } \\
\text { mendapatkan informasi tentang } \\
\text { penjualan dengan cepat dan } \\
\text { mudah }\end{array}$ & & & & \\
\hline
\end{tabular}

Berdasarkan hasil uji responden yang dilakukan, dapat disimpulkan bahwa:

a) Apakah interface sistem yang dibuat telah user friendly (mudah digunakan oleh pengguna). Sebagian besar responden menjawab setuju dengan detail penilaian: 2 jawaban sangat setuju, 8 jawaban setuju, 0 jawaban kurang setuju dan 0 jawaban tidak setuju.

b) Melihat laporan pada sistem informasi persediaan suku cadang barang lebih cepat dan mudah untuk di ingat dibandingkan dengan pemberitahuan laporan secara manual. Sebagian besar responden menjawab setuju dengan detail penilaian: 2 jawaban sangat setuju, 7 jawaban setuju, 1 jawaban kurang setuju dan 0 jawaban tidak setuju.

c) Apakah form pengisian pada add barang telah sesuai dengan form pengisian manual. Sebagian besar responden menjawab setuju dengan detail penilaian: 0 jawaban sangat setuju, 8 jawaban setuju, 2 jawaban kurang setuju dan 0 jawaban tidak setuju.

d) Sistem informasi persediaan suku cadang barang dapat membantu kepala cabang dan kepala wilayah untuk mendapatkan informasi tentang penjualan dengan cepat dan mudah. Sebagian besar responden menjawab setuju dengan detail penilaian: 1 jawaban sangat setuju, 9 jawaban setuju, 0 jawaban kurang setuju dan 0 jawaban tidak setuju.

Grafik hasil pengujian terhadap pengguna dapat dilihat pada Gambar 6 berikut ini:

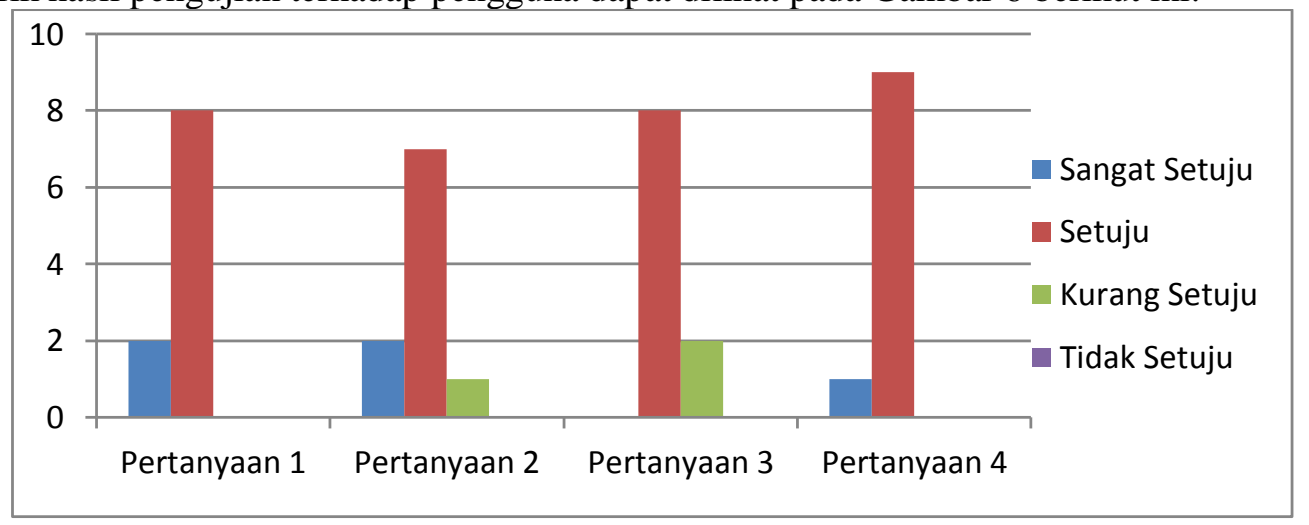

Gambar 6. Grafik Hasil Pengujian Pengguna

\section{5) Penyerahan}

Sistem Informasi Persediaan Suku Cadang Barang Berbasis Web pada Bengkel Daya Motor Palembang yang dirancang telah diserahkan pada Bengkel Daya Motor Palembang di terima oleh Kepada Pimpinan Bengkel Daya Motor yaitu Bapak Jemmy Herdiansyah.

\section{KESIMPULAN}

Berdasarkan hasil analisis dan pengujian system informasi persediaan suku cadang barang yang telah dilakukan maka dapat diambil beberapa kesimpulan yaitu pertama, sistem dapat membantu kegiatan-kegiatan transaksi dan melakukan rekapitulasi laporan pada Bengkel Daya Motor sehingga mempermudah pimpinan. Kedua, sistem informasi persediaan suku cadang barang yang dibangun menggunakan metode pengembangan sistem model Air 
Terjun (Waterfall), $P H P$ sebagai bahasa pemrograman, dan menggunakan perancangan sistem Data Flow Diagram (DFD) karena sistem yang dirancang berstruktur, dan dapat memberikan akses secara online kepada pengguna dengan berbasis web.

\section{DAFTAR RUJUKAN}

Indrajit, R. E., \& Djokopranolo, R. (2006). Konsep manajemen supply chain: cara baru memandang mata rantai penyediaan barang. In Grasindo.

Nugrahanti, F. (2015). Perancangan Sistem Informasi Inventory Sparepart Mesin Fotocopy Dengan Menggunakan Visual Delphi 7 (Studi Kasus di UD. Eka Taruna Madiun). Seminar Nasional Teknologi Informasi Dan Komunikasi, 364-372.

Pranggono, N. M., Irawati, T., \& Laksito, W. (2016). Sistem Informasi Persediaan Barang Secara Multiuser Pada Apotik Kinasih Bulu Sukoharjo Dengan Metode Rata-Rata Bergerak. Akuntansi, 14.

Pressman, R. S. (2012). Rekayasa Perangkat Lunak - Buku Satu, Pendekatan Praktisi. In Software Engineering: A Practitioner's Approach, Seventh Edition. https://doi.org/10.1098/rspb.2012.1110

Rahmad, M. B., \& Setiady, T. (2014). Perancangan Sistem Informasi Inventory Spare Part Elektronik Berbasis Web Php. Jurnal Sarjana Teknik Informatika, 2, 256-265.

Shalahuddin, R. A. . M. (2018). Rekayasa Perangkat Lunak Terstruktur. In Informatika.

Yulianti, L., \& Yupianti. (2012). Sistem Informasi Persediaan Barang Pada Pt. Surya Nusa Bhaktindo Bengkulu. Akuntansi, 8(1), 28. 